\section{THE TEACHER AS A FACTOR OF IMPROVING THE EFFECTS OF PHYSICAL EDUCATION CLASSES AMONG YOUNGER SCHOOL AGE CHILDREN}

\author{
NASTAVNIK KAO FAKTOR \\ POBOLJŠANJA EFEKATA \\ NASTAVE FIZIČKOG \\ VASPITANJA UČENIKA \\ MLAĐEG ŠKOLSKOG UZRASTA
}

\section{ABSTRACT}

The aim of this research was to present the effects of an experimental program including physical education classes among children aged 10-11. The experimental treatment lasted from March 1, 2010 to March 1, 2011, was realized in 16 elementary schools in the Republic of Srpska/B-H, and included the volunteer work of 20 physical education professors with no previous work experience with fourth and fifth grade students, that is, teachers, who in accordance with the law carry out the prescribed work with the aforementioned age group. The program included 1558 male and female students from city and suburb areas, 1213 of whom made up the experimental, and 345 the control group.

All of the participants were tested using the "EUROFIT" battery of tests. Seven variables from the area of motor skills were analyzed. The program was approved by the Ministry of Family, Youth and Sports and the Ministry of Education and Culture of the Republic of Srpska, and was realized in accordance with the national curriculum with the help of these two ministries, the Faculty of Physical Education and Sport of the University of Banja Luka and the Pedagogical Institute.

Following the completion of the initial and final measurements of the experimental and control group, the conclusion was reached that the students from the experimental group achieved statistically significant better results on the tests of motor skills. Considering that the experimental program lasted for one year, and that all the participants were tested using the same methods and under the same conditions, and after comparing the results of the final measurement, we could say that the work of the physical education teachers during physical education classes for younger school age children had a positive effect on the development of the tested motor skills of the students.

Keywords: teacher, physical education classes, younger school age

Moconja, G., Dobraš, R., Tadić, G., Kukrić, A., Petrović, B.\& Stojanović, D. (2018). Teacher as a factor of improvement of teaching physical education effects for younger school pupils. Sportlogia, 14 (1), 107-115.

doi:10.5550/sgia.181401.en.mdt 


\section{INTRODUCTION}

Younger school age students are constantly exposed to increased stress, starting with the fact that prior to staring school, by playing in a carefree manner they constantly moved and did not have any continued obligations. A change in lifestyle, which primarily refers to long-term sitting, and carrying a school bag, which is often inadequate and too heavy for the age of the students, provide favorable conditions for creating a physical disbalance, and thus the occurrence of milder and/or more severe forms of physical deformity. Precisely because of that, it is necessary for physical education classes for younger school age children to be adapted to their needs, and thus make up for at least one part of the movement needed at that age. Adequate and properly managed physical education classes certainly have a positive effect on the body and the physical status of students, but at the same time, any incompetently organized classes can certainly have a negative effect on their body, but also their motivation to participate in physical activities in the future.

The national curriculum for elementary education in the Republic of Srpska prescribes three physical education classes a week for younger school age children, from the second to the fourth grade (the Ministry of Education and Culture, 2006). The fact that this particular subject has the greatest number of weekly classes (right after the native language classes and math classes) is a clear indication of the importance of this subject for the younger school age children. The goals of physical education for students is to satisfy their need for movement, preserve and fortify their health and healthy habits, the development of motor skills and psychomotor features, especially flexibility, strength, speed, agility, to accustom the body to more difficult and complex movement, overcoming and acquiring the basic techniques of particular sports, develop positive moral-voluntary features, prepare students for the practical application of the acquired content in everyday life, and thus the development of work habits. (Hadžikadunić \& Mađarević, 2004). In the case of the number of weekly physical education classes, that is, the required weekly frequency of physical activity of the students, most authors, such as Findak (1989), prescribe a minimum of 30 to 60 minutes of physical activity a day, in order to provide for the proper development of the child (Strong, Malina, Blimkie, Daniels, Dishman, Gutin, Hergenroeder, Must, Nixon, Pivarnik, Rowland, Trost \& Trudeau, 2005; Pate, Davis, Robinson, Stone, McKenzie \& Young, 2006). Motor skills include human abilities which are included in solving motor tasks and which condition successful movement, irrespective of whether these abilities are acquired through training or not (Malacko, 1991). During growth and development, children pass through sensitive phases for motor development, that is, periods when it is most suitable to use systematic exercise to influence the development of certain abilities. These sensitive phases are periods when the systems of the human responsible for a certain ability undergo the greatest changes and are considered the most suitable for applying training for the development of these abilities. Bearing in mind precisely this fact, it is necessary to devote much more attention to the more professional physical education classes for students of a younger school age, as well as adhere to the prescribed number of classes for students of this age.

Classroom teachers in elementary schools in the Republic of Srpska who during their education attended the obligatory course Methodology of Physical Education for a period of two semesters, are in charge of carrying out physical education classes for students of a particular age. However, according to a survey which was carried out for the needs of the Sport development strategy of the Republic of Srpska for 2008-2012, the Ministry of Family, Youth and Sports (2008) announced that of the overall 377 analyzed students, only 3,9\% of them

Moconja, G., Dobraš, R., Tadić, G., Kukrić, A., Petrović, B.\& Stojanović, D. (2018). Teacher as a factor of improvement of teaching physical education effects for younger school pupils. Sportlogia, 14 (1), 107-115.

doi:10.5550/sgia.181401.en.mdt

Page 108. 
responded that they had physical education classes three times a week, which is not even close to the recommended daily physical activities. The volunteers who carried out the experimental program are graduates of the Faculty of Physical Education and Sport, and were tasked, primarily, with carrying out physical education classes for the appropriate age groups, based on the national curriculum and adhering to the prescribed number of classes. Physical education teachers, when realizing the experimental program, carried out tasks in accordance with didactic principles (the principle of awareness, health-educational focus, practical applicability, obviousness, individualization, planned load, entertainment and relaxation, etc.), and submitted reports on the realization of the program and classes in general which provided control of the experimental program. They also acted in a motivated and responsible manner towards realizing the program, bearing in mind that they were aware of the importance of monitoring the development of the motor skills of students as a part of physical education classes. Over the past few years, authors from the US have especially focused on issues which are tied to the benefits of monitoring the physical development of children and youths within physical education classes (Keating \& Silverman, 2004; Harris \& Cale, 2006; Mahar \& Rowe, 2008; Morrow \& Ede, 2009). Namely, these authors confirm that at the end of the 1990's a new concept emerged in monitoring motor structures which speaks of the connection between motor skills and health, and which differs from the existing concepts and understanding of the measurements and monitoring of the values of the motor dimensions of children and youths.

The aim of this research was to determine the extent to which another approach to physical education classes of a younger school age, that is, carrying out physical education classes by physical education teachers (instead of classroom teachers) influences the motor skills of a particular age group.

\section{METHOD}

All of the participants were male/female fourth/fifth grade students, aged 10-11, who regularly attend physical education classes and do not have any physical impediments that would prevent them from attending these classes. The sample is homogenous and consists of a total of 1558 participants (790 male and 768 female students). The experimental group consisted of 1213 participants (634 male and 579 female students). The control group was made up of 345 participants (156 male and 189 female students). All of the students were tested using the "EUROFIT" battery of tests which is prescribed by the Committee for the development of Sport of the European Union. The "EUROFIT" battery of tests (Eurofit, 1993) is a set of nine simple tests which focus on flexibility, strength, endurance and power. Due to the lack of props and insufficient facilities of the school sports halls, it was not possible to perform two of the tests from the standard battery.

The following tests were used (Hadžikadunić, Rađo, Grozdanić \& Turković, 2000):

- Flamingo balance test (FLB) - general balance

- Hand tapping (PLT) - speed of alternate movement

- Seated forward bend (SAR) - agility of the hip joint

- Standing depth jump (SBJ) - explosive power of the leg muscles

- Sit-ups (SUP) - repetitive strength of the abdominal muscles and the flexor muscles in the hip joint

- Hanging pull-up (BAH) - static power of the arm and shoulder belt muscles

Moconja, G., Dobraš, R., Tadić, G., Kukrić, A., Petrović, B.\& Stojanović, D. (2018). Teacher as a factor of improvement of teaching physical education effects for younger school pupils. Sportlogia, 14 (1), 107-115. doi:10.5550/sgia.181401.en.mdt

Page 109. 
- Running an obstacle course $10 \times 5$ (SHR) - agility

The data compiled during the research were processed using descriptive and comparative statistics (the T- test for dependent samples and the T- test for independent samples) using the statistical package IBM SPSS Statistics.

\section{RESULTS}

By analyzing the statistics of both groups, it was determined that the values of the means of all the variables indicate a better result in the final measurement. The variance coefficients, as the representatives of group homogeneity, indicate that for most variables the studied sample does not represent a homogenous group. For this research, what was of special interest was studying the groups individually, as well as comparing them, and so the analysis of each individual group was undertaken. The members, both of the control and the experimental group individually, represent homogenous groups based on the results of the tests which most of the students can, more or less, successfully perform. The problem of homogeneity only emerges where the tasks are such that a great number of students cannot perform them, so certain students make up a special sub-sample within the group they belong to. The aforementioned particularly refers to the tests BAH, SUP and FLB.

The $\mathrm{T}$ test for dependent samples for the control group (Table 1) has indicated that the participants of the control group achieved better results on the final than the initial measurements. For the FLB and SAR test, this difference is not statistically significant, while for the other tests a significance was noted at the level 0.05 (SBJ, SUP, BAH) and 0.01 (SHR and PLT). The $T$ test for dependent samples for the experimental group (Table 2) showed that the experimental group realized better results on all the measured variables during the final measurement compared to the results achieved at the initial measurement, and this indicates the significance of these differences, which is at the 0.01 level. The significance of the difference for the variable SAR is at the 0.05 level.

Table 1. The differences between initial and final measurements of the control group

\begin{tabular}{lcccc}
\hline Variable & INI & FIN & T & p \\
\hline FLB & 1.73 & 1.82 & -1.708 & .089 \\
PLT & 16.46 & 15.71 & 3.944 & $\mathbf{. 0 0 0 *}$ \\
SAR & 18.12 & 17.93 & .605 & .546 \\
SBJ & 134.40 & 131.22 & -2.445 & $\mathbf{. 0 1 5} *$ \\
SUP & 17.10 & 17.95 & -2.510 & $\mathbf{. 0 1 3}$ \\
BAH & 13.61 & 15.17 & -2.317 & $\mathbf{. 0 2 1} *$ \\
SHR & 26.41 & 25.88 & 2.864 & $\mathbf{. 0 0 4}$ \\
\hline
\end{tabular}

Legend: INI - arithmetic mean of initial measurement; FIN - arithmetic mean of final measurement; $\mathrm{T}-\mathrm{t}$ test for dependent samples; $\mathrm{p}$ - coefficient of difference significance; * - statistically significant differences.

\footnotetext{
Moconja, G., Dobraš, R., Tadić, G., Kukrić, A., Petrović, B.\& Stojanović, D. (2018). Teacher as a factor of improvement of teaching physical education effects for younger school pupils. Sportlogia, 14 (1), 107-115. doi:10.5550/sgia.181401.en.mdt
} 
Table 2. The differences between initial and final measurements of the experimental group

\begin{tabular}{lcccc}
\hline Variable & INI & FIN & T & $\mathrm{p}$ \\
\hline FLB & 1.67 & 2.22 & -47.375 & $\mathbf{. 0 0 0} *$ \\
PLT & 16.94 & 14.56 & 11.738 & $\mathbf{. 0 0 0} *$ \\
SAR & 17.97 & 18.48 & -2.142 & $\mathbf{. 0 3 2}$ \\
SBJ & 134.16 & 140.56 & -9.350 & $\mathbf{. 0 0 0} *$ \\
SUP & 17.05 & 19.97 & -19.729 & $\mathbf{. 0 0 0} *$ \\
BAH & 13.24 & 18.19 & -11.903 & $\mathbf{. 0 0 0} *$ \\
SHR & 26.92 & 24.78 & 11.172 & $\mathbf{. 0 0 0}$ \\
\hline
\end{tabular}

Legend: INI - arithmetic mean of initial measurement; FIN - arithmetic mean of final measurement; $\mathrm{T}$ - $\mathrm{t}$ test for dependent samples; $\mathrm{p}$ - coefficient of difference significance; $*$ - statistically significant differences.

This research is of particular importance for the existence or lack of any differences between the control and experimental group. In order to obtain these data, the $\mathrm{T}$ test for independent samples was used. The $\mathrm{T}$ test for independent samples used on complete sample of participants (Table 3) indicated that there is no statistically significant difference in the achieved results at the initial measurement. This data is of special importance for the further course of the research, bearing in mind the extent of the homogeneity of the groups which will undergo the experimental procedure. For this sample this is of special importance, knowing that we cannot homogenize this group any further, since in that case it would be necessary to regroup children from various classes, which is impossible in practice. The lack of any significant differences of the tested groups at the initial measurement (Table 3) is expected, bearing in mind that the sample included students of the same age, who took part in the same physical education classes.

Table 3. Differences between groups on initial measurement

\begin{tabular}{lcccc}
\hline Varijable & Mean K & Mean E & $\mathrm{t}$ & $\mathrm{p}$ \\
\hline FLB & 1.73 & 1.67 & -1.339 & 0.245 \\
PLT & 16.46 & 16.94 & 1.540 & 0.124 \\
SAR & 18.12 & 17.97 & -0.298 & 0.725 \\
SBJ & 134.40 & 134.16 & -0.151 & 0.880 \\
SUP & 17.10 & 17.05 & -0.137 & 0.891 \\
BAH & 13.61 & 13.24 & -0.440 & 0.660 \\
SHR & 26.41 & 26.92 & 1.341 & 0.180 \\
\hline
\end{tabular}

Legenda: Mean $\mathrm{K}$ - the arithmetic mean of the control group; Mean E - the arithmetic mean of the experimental group; $\mathrm{t}-\mathrm{t}$ test for independent samples; $\mathrm{p}$ coefficient of difference significance; $*$ - statistically significant differences.

During the experimental program, which lasted for one year, for the students of the control group physical education classes were carried out in the usual manner by the classroom teacher. Physical education teachers worked with the students who were members of the experimental group, instead of their classroom teachers. Following the experimental program, final measurements were taken with the aim of comparing the results of the experimental and control group to determine the existence of possible differences (Table 4).

Moconja, G., Dobraš, R., Tadić, G., Kukrić, A., Petrović, B.\& Stojanović, D. (2018). Teacher as a factor of improvement of teaching physical education effects for younger school pupils. Sportlogia, 14 (1), 107-115.

doi:10.5550/sgia.181401.en.mdt

Page 111. 
Table 4. Differences between groups on final measurement

\begin{tabular}{lcccc}
\hline Varijable & Mean $\mathrm{K}$ & Mean E & $\mathrm{t}$ & $\mathrm{p}$ \\
\hline FLB & 1.82 & 2.22 & 11.072 & $\mathbf{0 . 0 0 0} *$ \\
PLT & 15.71 & 14.56 & -3.420 & $\mathbf{0 . 0 0 0}$ \\
SAR & 17.93 & 18.48 & 1.028 & 0.172 \\
SBJ & 131.22 & 140.56 & 5.190 & $\mathbf{0 . 0 0 0}$ \\
SUP & 17.95 & 19.97 & 5.955 & $\mathbf{0 . 0 0 0}$ \\
BAH & 15.17 & 18.19 & 2.658 & $\mathbf{0 . 0 0 2} *$ \\
SHR & 25.88 & 24.78 & -3.148 & $\mathbf{0 . 0 0 0}$ \\
\hline
\end{tabular}

Legenda: Mean $\mathrm{K}$ - the arithmetic mean of the control group; Mean E - the arithmetic mean of the experimental group; $\mathrm{t}-\mathrm{t}$ test for independent samples; $\mathrm{p}$ coefficient of difference significance; $*$ - statistically significant differences.

Table 4 presents the results of the $\mathrm{T}$ test for the experimental and control group at the final measurement. As can be seen from the aforementioned, there is a statistically significant difference for all the measured variables in favor of the experimental group, except for the variable SAR. The significance of the differences for the variables FLB, PLT, SBJ, SUP and SHR is at the 0.01 level of significance, while the significance of the variable BAH is at the 0.05 level.

\section{DISCUSSION}

Bearing in mind that all the participants where in the sensitive period motor skill development, it was expected that the $\mathrm{T}$ test for dependent samples for the control and experimental group in individual measurements would indicate that better results were achieved on the final measurement compared to the initial one. However, what is of key importance for this research is the existence of a difference between the groups of participants at the initial and final measurement, obtained by the $T$ test for independent samples, which tells us that there are statistically significant differences between the control and experimental group of participants at the final measurement.

$F L B$ : There is a statistically significant difference between the control and experimental group at the 0.01 level of significance $(\mathrm{p}=.000)$. The experimental group achieved better results. At the initial measurement the difference between the groups was not statistically significant.

PLT: There is a statistically significant difference between the control and experimental group at the 0.01 level of significance $(\mathrm{p}=.000)$. The experimental group achieved better results. At the initial measurement the difference was not statistically significant.

$S A R$ : The difference for the studied variable was not statistically significant $(\mathrm{p}=.172)$, although the experimental group achieved a slightly better result, but without statistical significance. It should be mentioned that when analyzing the results of the initial and final measurement, a statistically significant improvement was noted for the experimental group at the 0.05 level of significance ( $\mathrm{p}=0.032$ ), while the progress of the control group is not statistically significant. The explanation for the lack of any significant difference among the groups at the final measurement for the course variable can be found in the fact that the control group had better results at the initial measurement (although not statistically significant), while the experimental group was better at the final measurement.

Moconja, G., Dobraš, R., Tadić, G., Kukrić, A., Petrović, B.\& Stojanović, D. (2018). Teacher as a factor of improvement of teaching physical education effects for younger school pupils. Sportlogia, 14 (1), 107-115. doi:10.5550/sgia.181401.en.mdt

Page 112. 
$S B J$ : It was determined that the control and experimental group differ in a statistically significantly manner at the 0.01 level $(\mathrm{p}=.000)$. The experimental group achieved better results. At the initial measurement the results were similar.

SUP: For the studied variable it was determined that the control and experimental group differ in a statistically significant manner at the 0.01 level of significance $(\mathrm{p}=.000)$, in favor of the experimental group which achieved better results. At the initial measurement the results were almost equal.

$B A H$ : The control and experimental group differed in a statistically significant manner at the 0.01 level of significance ( $\mathrm{p}=.002)$ in favor of the experimental group. At the initial measurement the results were similar.

SHR: There is a statistically significant difference between the control and experimental group at the 0.01 level $(\mathrm{p}=.000)$. The experimental group achieved better results. At the initial measurement the results were similar.

It should be pointed out that the positive effects of developing motor skills can be seen through the regular realization of the curriculum. Zurc (2009) carried out a study which indicated that obligatory physical education classes in the elementary schools of Slovenia are not enough to meet the children's need for regular physical activity, and our case indicates how the regular physical education classes have a positive effect.

\section{CONCLUSION}

Based on the obtained research results, the following conclusions were made:

At the initial measurement for all the studied variables no statistically significant differences were noted between the control and experimental group.

At the final measurement the experimental group of participants achieved statistically significant better results on the motor tests, except for the variable SAR.

Based on the realized study and the year-long experimental program within which physical education teachers carried out physical education classes instead of classroom teachers, and in accordance with the obtained research results, it can be concluded that the students from the experimental group over the course of the year-long program achieved statistically significant results on the tests of motor skills.

The experimental group of students were provided with more professional physical education classes which led to better results on the tests of motor abilities, compared to the students of the same age who were not influenced by the experimental program.

The practical importance of the paper has both a narrow and broad scope. In a more narrow sense, it can be seen in the significant improvement of motor skills compared to the physical education classes of the students in the control group. At the same time, we should mention that physical education classes carried out in the schools included in the program also gained in importance, since there was a significant change in the attitude towards these types of classes (of the parents, school authorities, other teachers, classroom teachers...). In a broader sense, the contribution of the research lies in the very participation of the government of the Republic of Srpska in the realization of this research and the willingness to treat physical education among younger school age children in the way, due to the importance of this period in human development, it deserves.

Moconja, G., Dobraš, R., Tadić, G., Kukrić, A., Petrović, B.\& Stojanović, D. (2018). Teacher as a factor of improvement of teaching physical education effects for younger school pupils. Sportlogia, 14 (1), 107-115. doi:10.5550/sgia.181401.en.mdt

Page 113. 


\section{REFERENCES}

Eurofit (1993). Eurofit Tests of Physical Fitness, $2^{\text {nd }}$ Edition, Strasbourg, FRA.

Findak, V. (1989). Metodika tjelesne i zdravstvene kulture: priručnik za nastavnike razredne nastave. Školska knjiga. Zagreb.

Hadžikadunić, M., Rađo, I., Grozdanić, B., \& Turković, S. (2000). Priručnik za testiranje eurofit baterijom testova. Sarajevo, BiH: Madž.

Hadžikadunić, M., \& Mađarević, M. (2004). Metodika tjelesnog odgoja sa osnovama fiziologije tjelesnog vježbanja. Zenica, BiH. Pedagoški fakultet.

Harris, J., \& Cale, L., (2006). A review of children`s fitness testing. European Physical Education Review, 12(2), 201-225. https://doi.org/10.1177/1356336X06065359

Keating, X. D., \& Silverman, S. (2004). Teacher`s Use of Fitness Tests in School-Based Physical Education Programs. Measurement in Physical Education and Exercise Science, 8(3), 145165. https://doi.org/10.1207/s15327841mpee0803_2

Mahar, M. T., \& Rowe, D.A. (2008). Practical Guidelines for Valid and Reliable Youth Fitness Testing. Measurement in Physical Education and Exercise Science, 12, 126-145. https://doi.org/10.1080/10913670802216106

Malacko, J. (1991), Osnove sportskog treninga, Kibernetički pristup. Novi Sad, RS: Biblioteka Matice srpske.

Ministarstvo porodice, omladine i sporta. (2008). Strategija razvoja sporta u Republici Srpskoj za period 2008-2012. godine [Zvanični podaci].

Ministarstvo prosvjete i kulture. (2006). Nastavni plan i program za osnovnu školu, Prva trijada. Banja Luka, BiH: Autor.

Morrow, J. R., \& Ede, A. (2009). Research Quarterly for exercise and Sport Lecture Statewide Physical Fitness Testing: A BIG Waist or a BIG Waste? Research Quarterly for exercise and Sport, 80, 696-701.

https://doi.org/10.1080/02701367.2009.10599610

PMid:20025110

Pate, R. R., Davis, M. G., Robinson, T. N., Stone, E. J., McKenzie, T. L., \& Young, C.J. (2006). Promoting Physical Activity in Children and Youth - A Leadership Role for Schools. Circulation. Journal of American Heart Association, 114, 1214-1224. PMid: 16908770

Strong, W. B., Malina, R. M., Blimkie, C. J., Daniels, S. R., Dishman, R.K, Gutin, B., Hergenroeder, A. C., Must, A., Nixon, P. A., Pivarnik, J. M., Rowland, T., Trost, S., \& Trudeau, F. (2005). Evidence based on physical activity for schoolage youth. Journal of Pediatrics, 164, 732-737. https://doi.org/10.1016/j.jpeds.2005.01.055

PMid:15973308

Zurc, J. (2009). Veza između akademske kompetencije i fizičke aktivnosti mlađih učenika. In Bokan, B. (Eds.), Međunarodna naučna konferencija: Teorijski, metodološki i metodički aspekti fizičkog vaspitanja (pp. 84-88). Beograd, RS: Fakultet sporta i fizičkog vaspitanja.

\footnotetext{
Moconja, G., Dobraš, R., Tadić, G., Kukrić, A., Petrović, B.\& Stojanović, D. (2018). Teacher as a factor of improvement of teaching physical education effects for younger school pupils. Sportlogia, 14 (1), 107-115. doi:10.5550/sgia.181401.en.mdt
}

Page 114. 


\section{SAŽETAK}

Cilj ovog istraživanja je prikazati efekte eksperimentalnog tretmana u nastavi fizičkog vaspitanja kod djece uzrasta 10-11 godina. Eksperimentalni tretman je trajao u periodu 01.03.2010. do 01.03.2011. godine u 16 osnovnih škola Republike Srpske/BiH, koji je uključivao volontiranje 20 diplomiranih profesora fizičkog vaspitanja bez radnog iskustva u četvrtim i petim razredima osnovnih škola, koji su provodili nastavu fizičkog vaspitanja umjesto nastavnika razredne nastave, odnosno učitelja, koji u skladu sa zakonskim odredbama provode nastavu u navedenom uzrastu. Tretman je uključivao 1558 učenika i učenica iz gradskih i prigradskih sredina, od toga 1213 ispitanika je bilo u eksperimentalnoj, a 345 ispitanika u kontrolnoj grupi.

Svi učenici su testirani baterijom "Eurofit" testova, odnosno analizirano je sedam varijabli iz oblasti motoričkih sposobnosti. Tretman je odobren od strane Ministarstva porodice, omladine i sporta i Ministarstva prosvjete $i$ kulture Vlade Republike Srpske, a realizovan je $u$ skladu sa Nastavnim planom i programom u saradnji sa ova dva ministarstva, Fakultetom za fizičko vaspitanje i sport Univerziteta u Banjoj Luci i Republičkim pedagoškim zavodom.

Nakon izvršenog inicijalnog $i$ finalnog mjerenja eksperimentalne $i$ kontrolne grupe učenika, došlo se do zaključka da su učenici eksperimentalne grupe postigli statistički značajno bolje rezultate u testovima motoričkih sposobnosti. Budući da je eksperimentalni tretman trajao godinu dana, i da su svi ispitanici testirani istim metodama u istim uslovima, a uvidom u poređene rezultate finalnog mjerenja, može se reći da je rad diplomiranih profesora fizičkog vaspitanja u nastavi fizičkog vaspitanja mlađeg školskog uzrasta pozitivno uticao na razvijanje testiranih motoričkih sposobnosti učenika.

Ključne riječi: nastavnik, nastava fizičkog vaspitanja, mlađi školski uzrast

Received: 25.05.2018. Accepted: 03.06.2018.

Coresponding author:

Gorica Bilak - Moconja,

Master of Science in Physical Culture,

Senior Associate for School Sports in the Ministry of Family, Youth and Sports,

Republic of Srpska, B\&H

\footnotetext{
Moconja, G., Dobraš, R., Tadić, G., Kukrić, A., Petrović, B.\& Stojanović, D. (2018). Teacher as a factor of improvement of teaching physical education effects for younger school pupils. Sportlogia, 14 (1), 107-115. doi:10.5550/sgia.181401.en.mdt
}

Page 115. 